\title{
UNIT KESEHATAN SEKOLAH SEHAT JIWA (UKS HAJI) (PROGRAM PENGABDIAN MASYARAKAT/IPTEK BAGI MASYARAKAT)
}

\author{
Ahmad Guntur Alfianto ${ }^{1}$, Ferdianto, R.N ${ }^{2}$, Lena SekarWati ${ }^{3}$, Julian M.'Noer Size ${ }^{4}$ \\ Program Studi Ilmu Keperawatan, Stikes Widyagama Husada Malang 1,2,3,4 \\ email: 15589ahmadguntur@gmail.com
}

\begin{abstract}
The formation of School Health Service Unit (UKS) for mental health is one of the form of mental health community service. The activity of UKS for mentl health are implemented through teacher's training about early detection of psychosocial problems and psychological first aid, elucidation of bullying and depression, electing the UKS's cadre and assertive training in prevent smoking behavior. This social health service programme were held at MTs Nurul Huda Bantur. The purpose of this activity is to trainned the teachers and students in order to prevent psycosocial problems in their surrounding and to elect the health cadres. The results show there were improvement in teacher's ability to making early detection and providing first aid in preventing bullying and depression after the training, and the students show assertive behavior about smoking after given assertive training and electing the health cadres. The conclusion of UKS for mrntal health activity is that both the teachers and students are able to prevent psycosocial problems in their surrounding environment. And it suggested that it is important to making a training for student's mental health cadres for the next health social service project.
\end{abstract}

Key words : school, UKS, mental health

\section{PENDAHULUAN}

Prevalensi kejadian ganggun jiwa di dunia pada tahun 2013 mencapai 450 juta orang dengan gangguan jiwa (WHO and World Health Organization, 2013). Hasil Riset kesehatan dasar tahun 2013 di Indonesia menunjukkan bahwa gangguan jiwa mental emosional yang ditunjukkan dengan gejala-gejala depresi dan kecemasan adalah sebesar $6 \%$ untuk usia 15 tahun ke atas atau sekitar 14 juta orang. Sedangkan, prevalensi gangguan jiwa berat, seperti schizophrenia adalah 1,7 per 1000 penduduk atau sekitar 400.000 orang (Badan Penelitian dan Pengembangan Kesehatan, 2013).

Studi pendahuluan yang dilakukan di puskemas Bantur kabupaten Malang memiliki ODGJ terbanyak di kabupeten Malang yang sudah teridentifikasi oleh dinas kesehatan kabupaten Malang. Pada tahun 2014 teridentifikasi ODGJ sebanyak 107 orang di wilayah kerja puskemas Bantur. Desa Bantur salah satunya desa yang memiliki ODGJ terbanyak diantara desa lainya. 
Faktor presipitasi dan predisposisi salah salatunya yang dialami oleh ODGJ adalah masalah psikososial. Masalah tersebut muncul seperti menarik diri, malas melakukan aktifitas, cemas, depersi, merasa kehilangan dan berduka, gangguan konsep diri, tidak mandi hingga malas untuk mandi (Stuart G.W. \& Laraia M.T., 2013). Hal tersebut di sebabkan karena masalah konflik dengan saudara, teman, perceraian, bullying, hinggak kenakalan remaja salah satunya di lingkungan sekolah. Upaya sedini mungkin untuk mencegah terjadinya masalah ganggun jiwa ataupun psikososial dilingkungan sekolah adalah memalui pelayanan kesehatan jiwa disekolah tersebut (Hunt and Eisenberg, 2010).

Pelayanan keperawatan adalah bagian integral dari pelayanan kesehatan di rumah sakit dan komunitas. Jumlah orang dengan gangguan jiwa (ODGJ) yang semakin bertambah dari tahun ke tahun tidak diimbangi dengan jumlah tenaga kesehatan dan kapasitas dari rumah sakit (Deacon, 2008). Hal ini menyebabkan munculnya pengembangan sistem pelayanan keperawatan yang pada awalnya berbasis clinical setting menjadi community setting. Selain itu, pentingnya peran keluarga dan masyarakat dalam membantu meningkatkan kemampuan klien dan mencegah kekambuhan menjadi salah satu alasan utama pentingnya penerapan asuhan keperawatan jiwa dengan pendekatan Community Mental Health Nursing (CMHN)(Keliat, 2011).

Salah satu konsep pengembangan CMHN adalah terbentuknya Desa Siaga Sehat Jiwa (DSSJ). Upaya dalam pembentukan DSSJ salah satunya dengan pemberdayaan di masyarakat oleh tenaga kesehatan. Bentuk pemberdayaan tersebut salah satunya bekerjasama dengan lintas sektor seperti sekolah yang berada di desa Bantur untuk mencegah terjadinya masalah psikososial dan ODGJ dikalangan remaja atau anak usia sekolah (Olowokere and Okanlawon, 2014). Berdasarkan masalah tersebut, maka perlu dilakukan penerapan asuhan keperawatan jiwa dengan pendekatan CMHN berbasis pemberdayaan di lingkungan sekolah di Desa Bantur. Salah satunya pembentukan UKS sehat jiwa di lingkungan sekolah.

\section{PERMASALAHAN}

MTs Nurul Huda salah satu sekolah setingkat SMP yang berada di di Dusun Durmo Desa Bantur. MTs tersebut satu-satunya MTs di Desa Bantur yang memiliki siswa terbanyak dan fsilitas asrama/pondok untuk siswa baik laki-laki ataupun perempuan.

Sejak tahun berdirinya mulai tahun 1992, MTs Nurul Huda memiliki masalah dikalangan siswanya. Masalah tersebut antara laian:

1. sering terjadi Bullying baik bullying fisik ataupun ucapan antara siswa sehingga orang tua saling mengadu ke pihak sekolah;

2. Kenakalan remaja (merokok, berkelahi antar teman);

3. Berhenti sekolah karena dipaksa oleh orang tuanya menikah dini; 
4. Anak sering tidak masuk sekolah karena malu tidak memiliki sepatu yang bagus;

5. Hingga anak berhenti sekolah karena takut dimarahi oleh guru jika tidak mengerjakan PR atau megalami kesealahan.

\section{METODE PENELITIAN}

Tabel 1. Metode Penelitian

\begin{tabular}{|c|c|c|}
\hline $\mathrm{No}$ & Kegaiatan/program & Luaran \\
\hline 1 & $\begin{array}{l}\text { Pelatihan deteksi dini masalah psikosial } \\
\text { dilungungkan sekolah oleh dewan guru }\end{array}$ & $\begin{array}{l}\text { 1. Modul Pelatihan } \\
\text { 2. Materi } \\
\text { 3. Lembar deteksi dini }\end{array}$ \\
\hline 2 & $\begin{array}{l}\text { Pelatihan konseling siswa bagi dewan } \\
\text { guru }\end{array}$ & $\begin{array}{l}\text { 1. Modul Pelatihan } \\
\text { 2. Materi } \\
\text { 3. Sertifikat }\end{array}$ \\
\hline 3 & $\begin{array}{l}\text { Penyuluhan dan terapi asertif tentang } \\
\text { perilaku berisiko dikalangan remaja }\end{array}$ & $\begin{array}{l}\text { 1. Modul } \\
\text { 2. Buku kerja } \\
\text { 3. Lembar balik } \\
\text { 4. Leafet }\end{array}$ \\
\hline 4 & $\begin{array}{l}\text { Pembentukan kader UKS Sehat Jiwa } \\
\text { bagi siswa }\end{array}$ & $\begin{array}{l}\text { 1. Materi } \\
\text { 2. Sertifikat }\end{array}$ \\
\hline 5 & Pembentukan UKS Sehat jiwa & 1. Sertifikat \\
\hline
\end{tabular}

\section{HASIL DAN PEMBAHASAN}

Hasil yang dicapai dalam kegiatan pengabdian pada masyarakat tentang UKS Haji adalah:

1. Kegiatan awal yang dilakukan tim pengabdian masyarakat adalah membentuk tim UKS Haji. Tim terbentuk dari dosen dan mahasiswa yang diketuai oleh Ahmad Guntur Alfianto salah satu dosen ilmu keperawatan dengan peminatan keperawatan jiwa, sedangkan anggota terdiri dari 4 mahasiswa dari program studi ilmu keperawatan STIKES Widyagama Husada. Mahasiswa tersebut adalah Julian Mahendra (keperawatan semester 4), Ferdianti R. Nene (keperawatan semester 4), Lisye (keperawatan semester 4), Lena Sekarwati (keperawatan semester 2) dan Noer Size (keperawatan semester 2).

Pembentukan tim tersebut merumuskan kepengurusan terkait kegiatan pengabdian masyarakat UKS Haji yang dilaksanakan di MTs Nurul Huda Bantur. Pemilihan tempat tersebut karena kecamatan Bantur salah satu kecamatan yang memiliki masalah kesehatan jiwa yang cukup tinggi di Kabupaten Malang. Selaian itu MTs Nurul Huda juga memiliki permasalahan terkait masalah psikososial yang cukup sering terjadi seperti bullying, perkelahian antara teman, merokok hingga putus sekolah.

Hasil dari diskusi penentuan tema UKS Haji disajikan pada tabel 2. 
Tabel 2. Hasil diskusi tim UKS Haji

\begin{tabular}{|c|c|c|}
\hline No. & Hasil diskusi & Alasan \\
\hline 1. & $\begin{array}{l}\text { Penyuluhan kepada siswa terkait } \\
\text { dampak Bullying }\end{array}$ & $\begin{array}{l}\text { Bullying salah satu aktivitas yang sering } \\
\text { dilakukan oleh seseorang baik disengaja } \\
\text { ataupun tidak disengaja yang berdampak ke } \\
\text { masalah psikososial terutama pada usia } \\
\text { remaja antara usia } 15-25 \text { tahun }\end{array}$ \\
\hline 2. & $\begin{array}{l}\text { Penyuluhan tentang NAPZA } \\
\text { pada siswa siswi MTs Nurul } \\
\text { Huda }\end{array}$ & $\begin{array}{l}\text { Pada usia sekolah saat ini memiliki } \\
\text { kebiasaan merokok. akibat merokok akan } \\
\text { berdampak kepada masalah kesehatan salah } \\
\text { satunya adalah kesehatan fisik. }\end{array}$ \\
\hline 3. & $\begin{array}{l}\text { Penyuluhan tentang depresi usai } \\
\text { sekolah pada siswa siswi MTs } \\
\text { Nurul Huda }\end{array}$ & $\begin{array}{l}\text { Usia remaja atau usia sekolah sangat } \\
\text { berisiko terjadinya masalah psikososial } \\
\text { seperti cemas, stress dan depersi. } \\
\text { Masalah tersebut timbul akibat pengaruh } \\
\text { teman sebaya, bullying, hingga masalah } \\
\text { menghadapi ujian sekolah. }\end{array}$ \\
\hline
\end{tabular}

Kegiatan pembentuk tim pengabdian pada masyrakat tersebut dilaksanakan di perpustakaan STIKES Widyagama Husada kampus B pada pukul 13.00 dan dilaksanakan pada tanggal 23 Juli 2018.

2. Penyusunan program yang dilaksanakan pada tanggal 25 Juli 2018 di Rumah kepala sekolah MTs Nurul Huda yaitu ibu Siti Zulaicoh, SS., M. Pd. Pembahasana masalah tersebut di ikuti oleh ketua tim Ahmad Guntur Alfianto dan anggota seperti Julian Mahendra, Ferdianto R. Nene, Lena Sekarwati dan Noer Size. Kegiatan tersebut membahas masalah kegiatan pengabdian masyarakat terkait UKS Haji. Hasil diskusi tersebut adalah:

3.

Tabel 3. Analisis masalah kesehatan jiwa siswa di MTs Nurul Huda

No. Masalah kesehatan jiwa di lingkungan Solusi yang ditawarkan sekolah

1. Motivasi orang tua terkait masalah Penyuluahan pendidikan terutama anak setelah lulus sekolah segera dinikahkan

2. Sebagian guru tidak peduli jika ada permasalahan siswa yang sangat serius cenderung semua di limpahkan kepada kepala sekolah.

3. Masalah bullying yang sering terjadi sehingga anak dan orang tua sering terjadi masalah dan melaporkan ke pihak yayasan

4. Anak cenderung tidak masuk sekolah jika ada masalah dengan keluarga dan teman sebayanya atau lingkungan sekolah (seperti guru yang memukul siswa dan lainPelatihan konseling salah satunya pelatihan pertolongan pertama psikologi bagi guru

Penyuluhan bullying

Penyuluhan dan pelatihan deteksi dini pada siswa yang mengalami masalah psikososial lainnya) 


\begin{tabular}{lll}
\hline 5. Dilingkungan luar sekolah banyak siswa & Pelatihan asertif tetang berhenti \\
yang merokok, salah satunya sebelum & merokok \\
berangkat sekolah guru-guru sering & \\
menemui siswa yang merokok di jalan. & \\
6. & Program kesehatan jiwa di siswa & Pembentukan UKS Haji \\
\hline
\end{tabular}

Kegiatan UKS Haji yang dilaksanakan MTs Nurul Huda dilakukan seminggu 1 kali dengan pembinaan berupa pelatihan deteksi dini masalah psikososial siswa, pelatihan pertolongan pertama psikologis pada guru, penyuluhan tentang bullying, NAPZA dan depresi serta pelatihan asertif tentang NAPZA. Pembinaan disepakati untuk penyuluhan dan pelatihan asertif di masjdi Nurul Huda sedangkan untuk pelatihan dengan guru dilaksanakan di ruang kelas.

3. Pelatihan deteksi dini dan pertolongan pertama psikologi pada guru MTs Nurul Huda.

Pelatihan ini dilaksankan di ruang kelas MTs Nurul Huda. Kegiatan tersebut dilaksanakan pada tanggal 4 Agustus 2018. Kegiatan pelatihan tersebut meliputi ceramah dan diskusi serta melakukan praktik tentang pertolongan peratama psiklogis. Pelatihan tersebut di ikuti sebanyak 21 Guru MTs Nurul Huda.

Selama kegiatan berlangsung beberapa guru menanyakan terkait masalah kesehatan jiwa remaja seperti masalaha bullying, merokok serta anak yang tidak masuk sekolah karena malu tidak memakai sepatu atau takut dengan teman sebayanya. Upaya dari permasalahan tersebut salah satunya dengan melatiah guru untuk menjadi pendegar yang aktif ketika ada masalah pada siswanya. Seperti melakukan pendampingan hingga memberikan pertolongan pertama psikologis.

Refleksi hasil pelatihan pertolongan pertama psikologis pada guru MTs Nurul Huda.

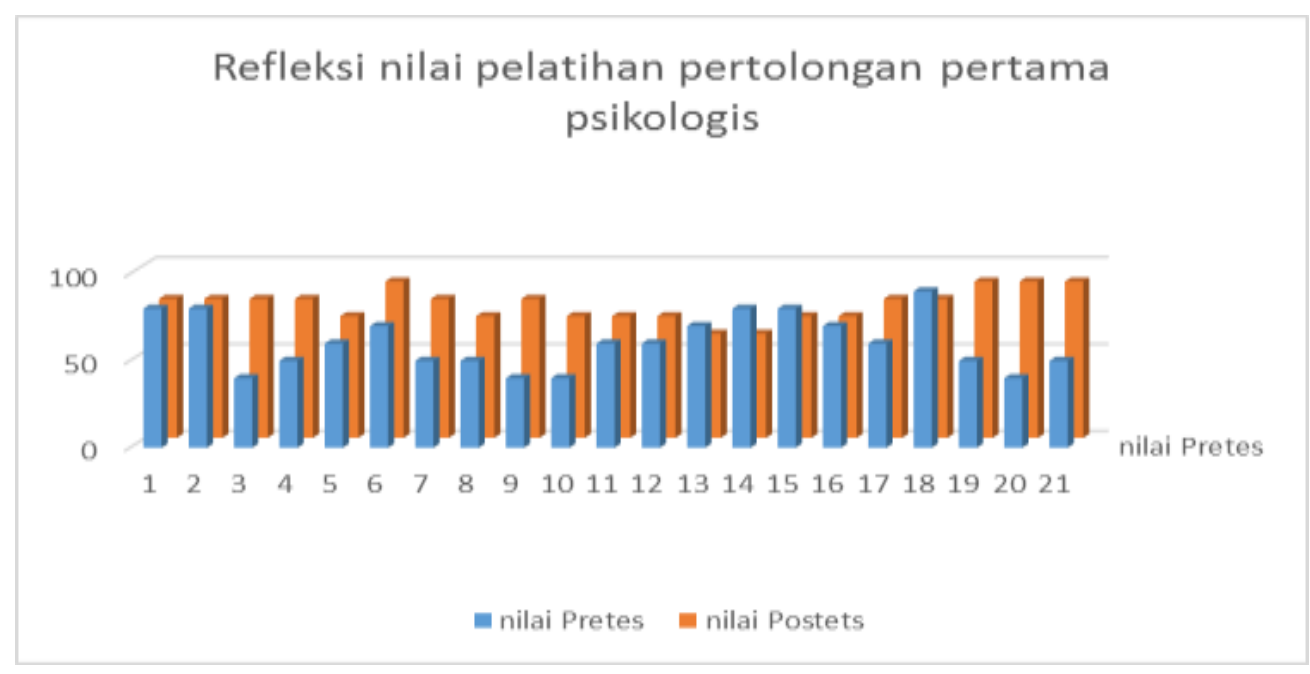

Gambar 1. Nilai sebelum dan sesudah diberikan pelatihan dalam praktik melakukan pertolongan pertama psikologis pada guru MTs Nurul Huda. 
Hasil pelatihan yang didapatkan adalah terjadi peningkatan kemampuan dalam melakukan pertolongan pertama psikologis. Nilai rata-rata yang didapatkan sebelum pelatihan adalah 60,48 sedangkan nilai rata-rata sesudah diberikan pelatihan adalah 76,67. Instrumen untuk mengukur kemampuan guru-guru dalam melakukan pertolongan pertama psikologis adalah dengan menggunakan SOP pertolongan pertama yang di modifikasi dari panduan WHO terkait pertolongan pertama. Selain itu SOP tersebut sudah di uji kepada 5 Mahasiswa keperawatan sebelumnya.

4. Penyuluhan tentang pencegahan Bullying di siswa MTs Nurul Huda

Kegiatan penyuluhan tentang pencegahan bullying di siswa MTs Nurul Huda dilaksnakan pada tanggal 4 Agustus 2018 pada pukul 08.00 WIB di Masjid Nurul Huda. Penyuluhan tersebut disampikan oleh Julian Mahendra, Ferdianto R. Nenen, Lena Sekar Wati dan Noer Size. Penyampian materi disampaikan oleh Julian Mahendra dengan Moderator Ferdianto R. Nene.

Penyuluhan tersebut juga diukur dengan memberikan kuesioner tentang pemahaman bullying yang terdiri dari 10 soal.

Penyuluhan tersebut di ikuti oleh 42 Siswa. Antusias siswa tersebut di buktikan dengan peserta bertanya terkait masalah bullying serta dampak dan pencegahan bullying tersebut. Metode yang digunakan dalam penyuluhan tersebut adalah diskusi dan ceramah.

Refleksi hasil penyuluhan tentang bullying pada siswa MTs Nurul Huda terlihat pada gambar 2 .

Hasil penyuluhan tersebut memberikan dampak pada tingkat pengetahuan siswa MTs Nurul Huda Bantur. Hal tersebut terbukti dari nilai pengetahuan bullying sebelum diberikan penyuluhan yaitu 65,24. Sedangkan nilai dai pengetahuan setelah diberikan penyuluhan bullying adalah 84,05

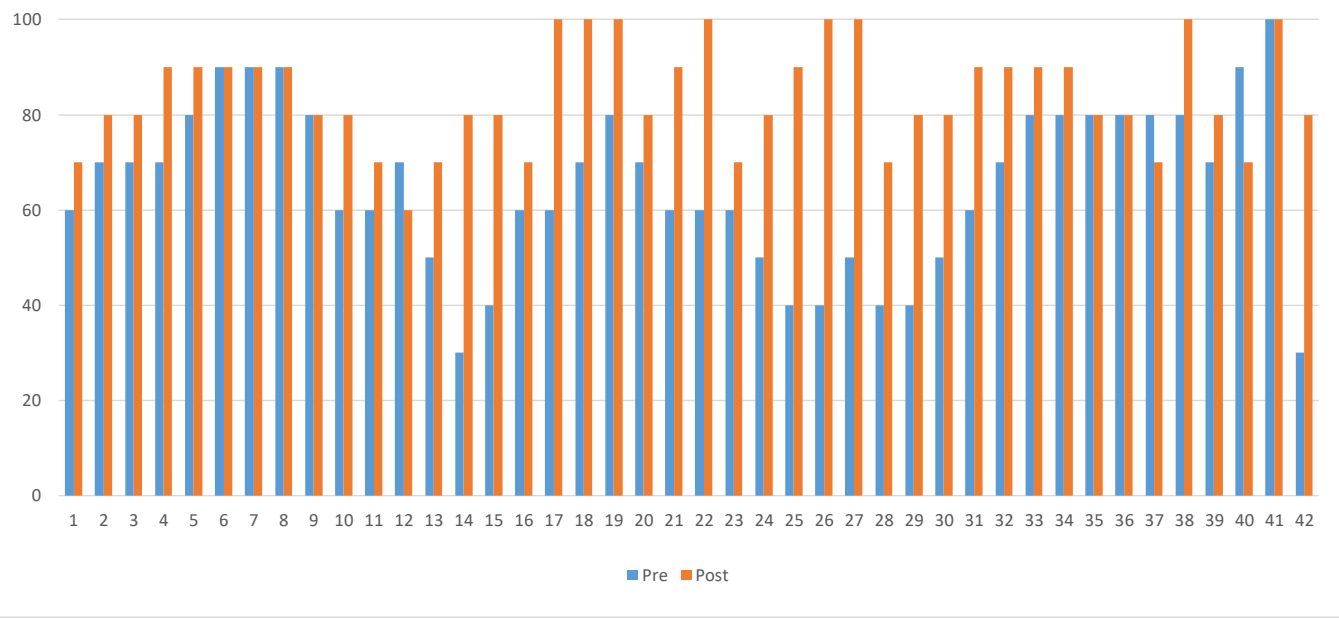

Gambar 2. Hasil nilai perbandingan sebelum dan sesudah penyuluhan bullying terhadap pengetahuan bullying pada siswa MTs. Nurul Huda 
5. Pelatihan Asertif dan penyuluhan terkait NAPZA

Pelatihan asertif salah satu tindakan mencegah pada perilaku menyimpang. Salah satu perilaku menyimpang pada remaja adala masalah NAPZA. Kasus pada siswa MTs Nurul Huda salah satunya adalah masalah perilaku merokok. Pelatihan dan penyuluhan asertif terhadap masalah NAPZA di ikuti oleh 39 siswa laki-laki dan perempuan, baik yang berisiko merokok atau yang sudah merokok. pelatihan tersebut dilakasakan pada tanggal 9 Agustus 2018 di Masji Nurul Huda. Pemateri yang menyampaikan adalah Ferdianto R, Nene dan Julian Mahendar. Sedangkan yang menjadi moderator adalah Lena Sekar Wati. Refleksi hasil pelatihan dan penyuluhan tentang pencegahan NAPZA pada siswa MTs Nurul Huda ditampilkan pada gambar 3.

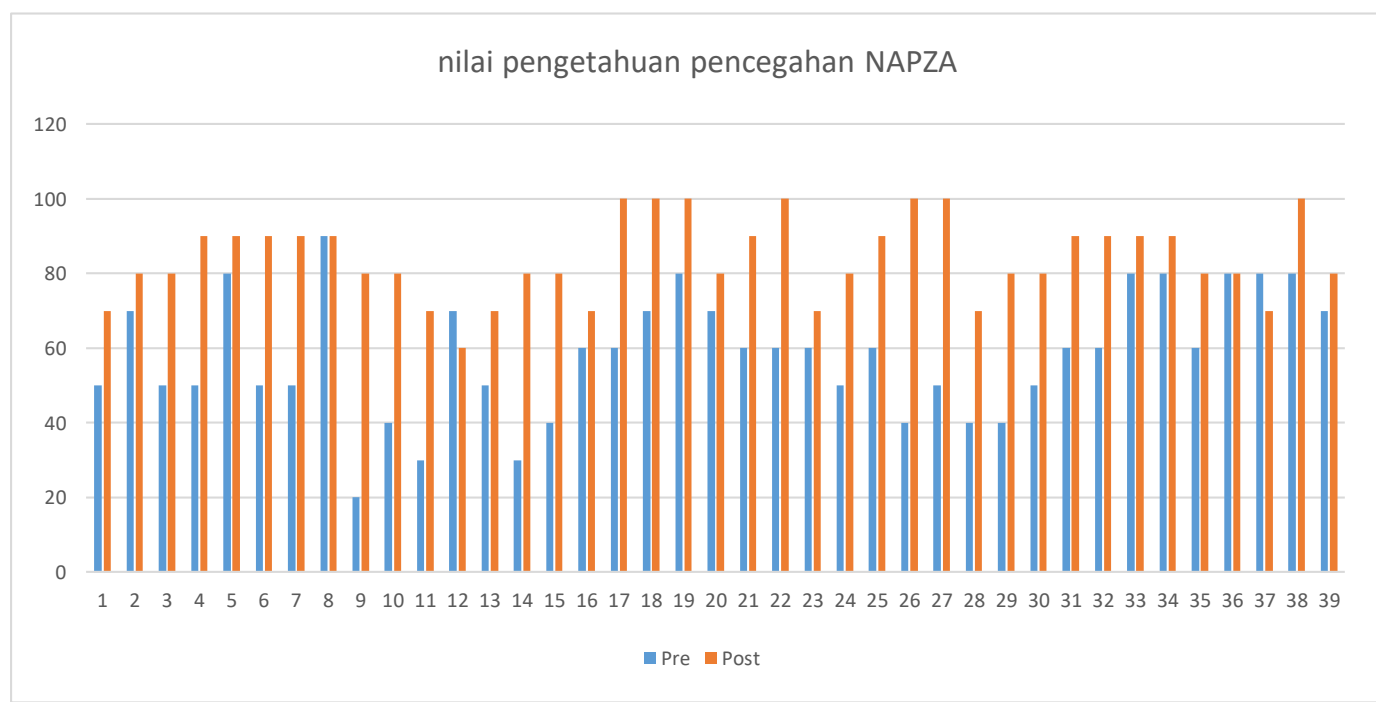

Gambar 3. Hasil nilai perbandingan sebelum dan sesudah pelatihan dan penyuluhan asertif terhadap pengetahuan pada siswa MTs. Nurul Huda tentang pencegahan NAPZA

Hasil pelatihan dan penyuluhan asertif tersebut memberikan dampak pada tingkat pengetahuan siswa MTs Nurul Huda Bantur tentang pencegahan NAPZA. Hal tersebut terbukti dari nilai pengetahuan pencegahan NAPZA sebelum diberikan pelatihan dan penyuluhan asertif yaitu 58,21. Sedangkan nilai dari pengetahuan tentang pencegahan NAPZA setelah diberikan pelatihan dan penyuluhan asertif adalah 84,10 .

6. Penyuluhan tentang depresi pada siswa atau remaja

Penyuluhan tentang depresi pada siswa ini dilaksanakan pada tanggal 18 Agustus 2018 di Masjid Nurul Huda. Peserta dari penyuluhan ini adalah siswa MTs Nurul Huda berjumlah 37 Siswa. Penyuluhan dilaksanakan pada pukul 09.00 WIB dengan metode diskusi dan ceramah.

Pemateri pada penyuluhan ini adalah Noer Size sedangkan moderatornya adalah Julian Mahendra. Kegiatan tersebut memberikan mnfaat terkait siswa dalam mengenali tanda gejala masalah psikososial terutama depersi stress dan 
cemas karena meghadapi ujian nasional, terdapat masalah dengan teman sebayanya, akibat bullying dan masalah lainya.

Pengukuran kemampuan dalam megenal tanda gejala depresi tersebut menggunakan kuesioner tentang pencegahan depersi pada siswa.

Refleksi hasil penyuluhan tentang pencegahan depresi pada siswa MTs Nurul Huda.

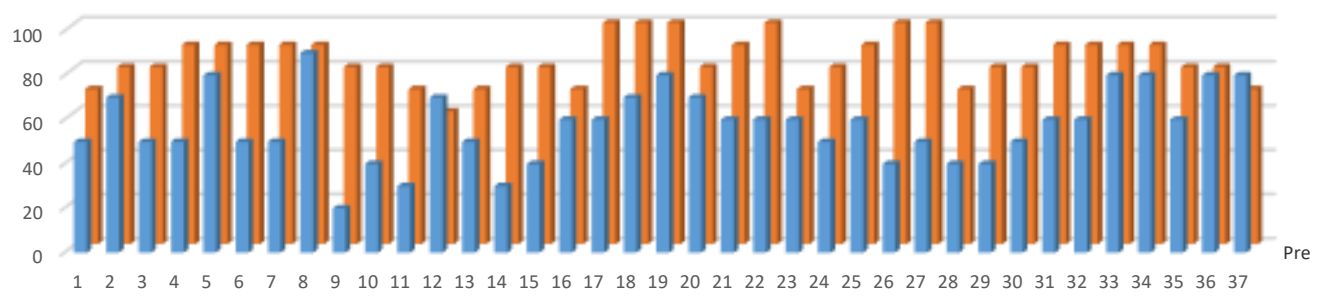

- Pre $\square$ Post

Gambar 4. Hasil nilai perbandingan sebelum dan sesudah penyuluhan depresi pada siswa terhadap pengetahuan pada siswa MTs. Nurul Huda tentang pencegahan depresi

Hasil penyuluhan depersi tersebut memberikan dampak pada tingkat pengetahuan siswa MTs Nurul Huda Bantur tentang pencegahan depresi. Hal tersebut terbukti dari nilai pengetahuan pencegahan depresi sebelum diberikan penyuluhan dpersi yaitu 57,30. Sedangkan nilai dari pengetahuan tentang pencegahan NAPZA setelah diberikan pelatihan dan penyuluhan asertif adalah 83,78 .

7. Pembentukan Kader siswa kesehatan jiwa di sekolah.

Pembentukan kader kesehatan jiwa disekolah ini dilksanakan pada tanggal 18 Agustus 2018. Kegiatan tersebuut memilih beberapa siswa yang bersedia menjadi keader kesehatan jiwa dan menjadi motivator bagi teman sebayanya jika mengalami masalah psikososial.

\section{KESIMPULAN DAN SARAN}

Pengabdiaan masyarakat UKS Haji dilakukan berupa:

1. Pelatihan kepada guru terkait deteksi dini masalah psikososial usia sekolah serta pelatihan pertolongan pertama psikologis pada guru untuk siswa yang megalami masalaha tanda gejala psikososial di lingkungan sekolah.

2. Penyuluhan terkait bullying pada siswa MTs Nurul Huda

3. Pelatihan asertif dan penyuluhan NAPZA pada siswa MTs Nurl Huda 
4. Penyuluhan tentang depresi pada siswa dengan sasaran siswa MTs Nurul Huda

5. Pembentukan kader siswa kesehatan jiwa di MTs Nurul Huda

Saran pada pengabdian masyarakat selanjutnya akan di laksanakan pelatihan kader siswa kesehatan jiwa di MTs Nurul Huda.

\section{UCAPAN TERIMAKASIH}

Pengabdian masyarakat ini didapatkan dari dana pengabdian masyarakat STIKES Widyagama Husada melalui program lembaga penelitian dan pengabdian Masyarakat Kewirausahaan (LPPMK) pada tahun 2018

\section{DAFTAR PUSTAKA}

Badan Penelitian dan Pengembangan Kesehatan (2013) 'Riset Kesehatan Dasar (RISKESDAS) 2013', BADAN PENELITIAN DAN PENGEMBANGAN KESEHATAN KEMENTERIAN KESEHATAN RI TAHUN 2013. doi: 1 Desember 2013.

WHO and World Health Organization (2013) 'Global action plan for the prevention and control

Keliat (2011) 'Keperawatan kesehatan Jiwa Komunitas: CMHN (Basic Course)', in buku kedokteran. doi: 10.1007/978-3-8348-8298-1.

Stuart G.W. \& Laraia M.T. (2013) Principle and practice of psychiatric nursing. Edition 10. St.Louis Missouri: Mosby Elsevier.

Deacon, M. (2008) 'Community Mental Health Nursing', in Mentorship in Community Nursing: Challenges and Opportunities. doi: 10.1002/9780470690536.ch11.

Hunt, J. and Eisenberg, D. (2010) 'Mental Health Problems and Help-Seeking Behavior Among College Students', Journal of Adolescent Health. doi: 10.1016/j.jadohealth.2009.08.008.

lowokere, A. E. and Okanlawon, F. A. (2014) 'The Effects of a School-Based

Psychosocial Intervention on Resilience and Health Outcomes Among Vulnerable Children', Journal of School Nursing. doi: 10.1177/1059840513501557. 